\title{
Analysis of the guiding rules of the nurse technician's practice in Brazil
}

\author{
Análise das normativas orientadoras da prática do técnico de enfermagem no Brasil \\ Análisis de las normativas que guían la práctica del técnico de enfermería en Brasil
}

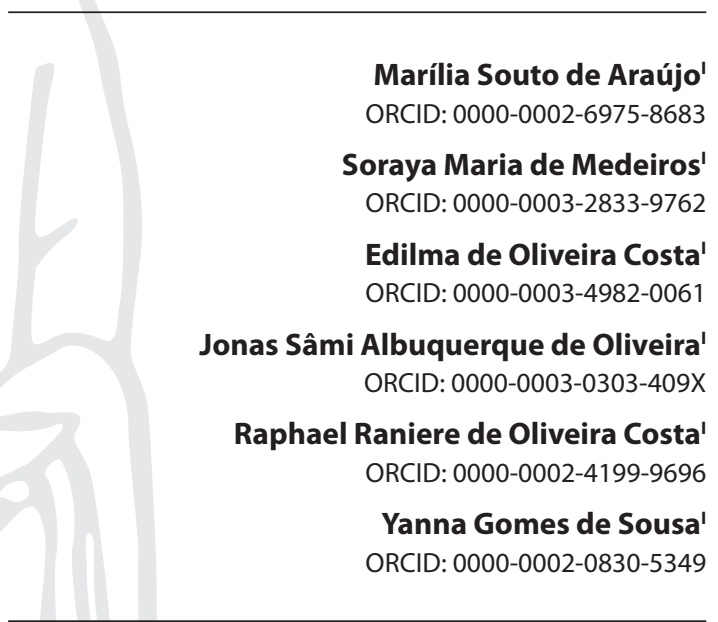

'Universidade Federal do Rio Grande do Norte. Natal, Rio Grande do Norte, Brazil.

How to cite this article: Araújo MS, Medeiros SM, Costa EO, Oliveira JSA, Costa RRO, Sousa YG. Analysis of the guiding rules of the nurse technician's practice in Brazil. Rev Bras Enferm. 2020;73(3):e20180322. doi: http://dx.doi.org/10.1590/0034-7167-2018-0322

\section{Corresponding author: \\ Marília Souto de Araújo \\ E-mail: mariliasdearaujo@yahoo.com.br}

EDITOR IN CHIEF: Dulce Aparecida Barbosa ASSOCIATE EDITOR: Dalvani Marques

Submission: 05-22-2018 Approval: 04-27-2019

\begin{abstract}
Objectives: to analyze the normative bases that guide the nurse technician's practice, clarifying how the performance of this category happens. Methods: this is a qualitative study of exploratory and descriptive nature and of documentary type, held on the basis of the resolutions of the Brazilian Federal Nursing Council (Cofen). From a total of 364 resolutions published from 1975 to 2018, 15 accounted for the objective of the study and were therefore selected. Results: this study systematized two analytical categories: areas of practice of the nurse technician, according to Cofen resolutions; and description of the professional's activities based on the resolutions. Final Considerations: the analysis of the normative bases that guide the nurse technician's practice leads to the conclusion of a possible frailty of theoretical and normative content to justify the practice of these professionals.

Descriptors: Professional Practice; Resolutions; Nursing Care; Area of Professional Performance; Nursing.
\end{abstract}

\section{RESUMO}

Objetivos: analisar os fundamentos normativos que orientam a prática do profissional técnico de enfermagem, esclarecendo como se dá a atuação dessa categoria. Métodos: trata-se de um estudo de abordagem qualitativa, de natureza exploratório-descritiva, do tipo documental, realizado com base nas resoluções do Conselho Federal de Enfermagem. De um total de 364 resoluções publicadas no período de 1975 a 2018, foram selecionadas 15 que atenderam ao objetivo do estudo. Resultados: foram sistematizadas duas categorias analíticas: âmbitos de atuação do técnico de enfermagem, segundo as resoluções do Conselho Federal de Enfermagem, e descrição das atividades do profissional com base nas resoluções. Considerações Finais: a análise dos fundamentos normativos que orientam a prática do técnico de enfermagem guia para a conclusão de possível fragilidade de conteúdo teórico e normativo para fundamentar a prática desses profissionais.

Descritores: Prática Profissional; Resoluções; Assistência de Enfermagem; Área de Atuação Profissional; Enfermagem.

\section{RESUMEN}

Objetivos: evaluar los fundamentos de las normativas que guían la práctica del profesional técnico de enfermería para aclarar cómo ocurre la actuación de esa categoría. Métodos: se trata de un estudio de enfoque cualitativo, de naturaleza exploratoria y descriptiva, de tipo documental, realizado con base en las resoluciones del Consejo Federal de Enfermería. De un total de 364 resoluciones publicadas en el período de 1975 a 2018, se seleccionaron 15 que cumplían con el objetivo del estudio. Resultados: se sistematizaron dos categorías analíticas: el nivel de actuación del técnico de enfermería, según exponen las resoluciones del Consejo Federal de Enfermería, y la descripción de las actividades del profesional con base en estas resoluciones. Consideraciones Finales: el análisis de los fundamentos de las normativas que guían la práctica del técnico de enfermería apunta a una posible debilidad de contenido teórico y normativo para fundamentar la práctica de estos profesionales. Descriptores: Práctica Profesional; Resoluciones; Atención de Enfermería; Ubicación de la Práctica Profesional; Enfermería. 


\section{INTRODUCTION}

The institutionalization of nursing as a profession is characterized by the division of labor, marked by discipline and hierarchy, with the participation of several active agents, among which we can cite the nurse, the nurse technician, the nursing assistant, and the nursing attendant. The latter, although mentioned in the legislation, has been extinct since the $1990 \mathrm{~s}^{(1-2)}$.

Each of the three professional categories still acting have a specific training process, which requires a separate set of activities. In Brazil, the nurse technician education was defined in the promulgation of law No. 5.692/71, and became part of the Educational System of the country in technical level, being regulated by resolution No. 07/77 of the Brazilian Federal Education Council(3).

Currently, the profession is inscribed in that featured in decrees, opinions, and resolutions concerning the Professional Education at a Technical Level, based on the law that established new guidelines and bases for national education, the Law of Guidelines and Bases (LDB) No. 9.394/17 ${ }^{(4)}$, and in harmony with the law of the professional practice of Nursing ruled by the Brazilian Federal Nursing Council (Cofen), since that, if dissociated from the rules governing the professional practice, causes conflicts between the different professional levels of nursing and promotes the illegal exercise of the profession.

It is important to note that, despite the establishment of a legislation that guides the nurse technician's practice, one has to consider the existence of social, cultural, political and economic factors that define this professional practice, which cannot be reached if detached from the Brazilian health context. These factors are often responsible for the deficiency of human and material resources, lack of training policies, among others, that can interfere with the professional practice and consequently in the quality of the assistance provided ${ }^{(5)}$.

Based on the considerations above, this study seeks to answer the following question: in light of the regulations issued by the Brazilian Federal Nursing Council, how is the nurse technician's professional practice characterized? deals with the practice of Nursing; and law No. 5.905/73(7), which covers the creation of Federal and Regional Nursing Councils. The survey scenario was the Cofen virtual page, which presents the guiding law of the practice of the profession of nurses, nurse technicians and nursing assistants.

\section{Type of study}

This is a qualitative study of exploratory and descriptive nature and of documentary type, held on the basis of the resolutions of the Brazilian Federal Nursing Council (Cofen), since its first edition in October 4, 1975 until the last one, in February 23, 2018.

\section{Methodological procedures}

For the organization of the documentary database, the Cofen resolutions were adopted as inclusion criteria, which were available in full, with free access. Exclusion criteria covered the resolutions that were repealed, prohibited or that did not comply with the goal of the study. The search of the documents was completed in February 2018, accounting for 364 resolutions.

\section{Study setting}

The virtual portal of the Brazilian Federal Nursing Council was the study setting.

\section{Data source}

This study used as data source the legislation present in the Cofen portal, available online ${ }^{(8)}$.

\section{Data collection and organization}

After this survey, all documents were read in full; from these, 15 met the objective of this study. Figure 1 shows the flowchart of the selection of documents.

\section{OBJETIVES}

To analyze the normative bases that guide the nurse technician's practice, clarifying how the performance of this category happens.

\section{METHODS}

\section{Ethical aspects}

Because this is a study that used secondary data from public documents available on the internet, it did not require a the presentation on Research Ethics Committee. It is still considered that the ethical aspects of document authoring were respected throughout the process.

\section{Theoretical and methodological framework}

The theoretical framework used the Decree No. $94.406 / 87^{(6)}$, which regulates law No. 7.498, issued in June $25,1986^{(2)}$, which

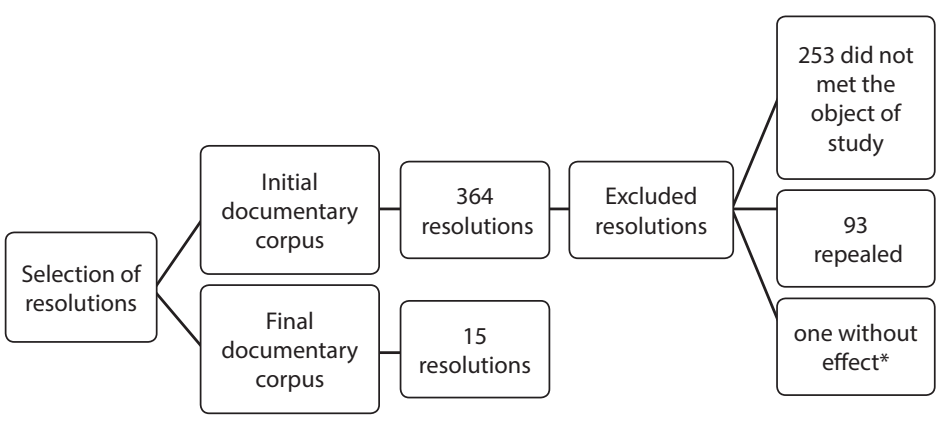

Note: *This is a transient suspensor resolution

Figure 1 - Flowchart of the selection of resolutions

\section{Data analysis}

The documents were analyzed by document analysis technique, which consisted of two steps: systematization of documents and summary of information ${ }^{(9)}$. In the first step, a table was built in Microsoft 
Word ${ }^{\circ}$ for preliminary evaluation of the documents, considering the context, key concepts and the internal logic of the text ${ }^{(9)}$.

In the second step, a similarity tree was obtained from the synthesis of documentary information by using the software program Interface de R pour les Analyses Multidimensionnelles de Textes et de Questionnaires (IRAMUTEQ) ${ }^{(10)}$. The similarity analysis is based on graph theory, identifying the co-occurrences of words and connectedness between terms, which contribute to the knowledge of the structure of a textual corpus ${ }^{(11)}$.

\section{RESULTS}

A total of 364 resolutions were examined; they were available online and published from 1975 to 2018 . Fifteen of them were selected for meeting the inclusion criteria and responding to the research question, as exposed in Chart 1.

From the resolutions selected, one could observe the presence of convergence on certain activities in resolutions as a whole. Considering the convergent activities, it is identified that in all resolutions of the sample, the practice as law No. $7.498 / 86^{(2)}$ and Decree No. $94.406 / 87^{(5)}$, record in medical chart, training of the professional, integration with the team, biosafety and the client education are key concepts, as shown in Figure 2.

All resolutions bring in the first article the statement that the nurse technician must perform nursing actions under the supervision of a nurse, as law No. 7.498/86 and Decree No. 94.406/87.

From the reading of the resolutions emerged, besides convergent activities, certain points concerning the scope of the nurse technician's practice that were not part of the general documentary corpus, but were present in specific resolutions. Based on these specificities, the following areas of practice were identified: chemotherapy; radiology; surgical center; pre-hospital service; orthopedics; nutritional therapy; home care; and hemotherapy.

Regarding the characterization of the work process of the nurse technician, according to the resolutions, in Chart 2 shows the characterization of the specific activities of each.

With the aim of detecting the connectivity of the elements considered structuring of the final documentary corpus of the study, the similarity analysis through the tree (Figure 3 ) resulting from the processing was submitted by the IRAMUTEQ software program. Through similarity analysis, one can identify the cooccurrences between words and its result indicate the connectivity between them, as well as the proximity of ideas. The results from this analysis confirmed an emphasis for the following words: nurse (12); patient (11); supervision (6); and perform (5). From the interpretation of the similarity tree, one can indicate the centrality of the content of resolutions about the nurse technician's role mainly associated to technical procedures, under supervision of the nurse professional.

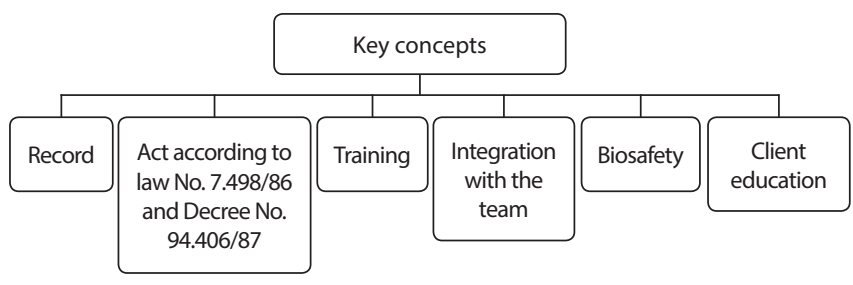

Figure $\mathbf{2}$ - Terms that converge in all resolutions of the sample

Chart 1 - Resolutions elected for the study sample

\begin{tabular}{|c|c|}
\hline $\begin{array}{l}\text { Conselho Fedeal de Enfermagem } \\
\text { resolution No./year }\end{array}$ & Title \\
\hline $210 / 1998$ & Provides for the professional practice of nurses that work with chemotherapeutic and antineoplastic substances. \\
\hline $211 / 1998$ & Provides for the professional practice of nurses that work with ionizing radiation. \\
\hline 214/1998 & Provides for surgical instrumentation. \\
\hline $358 / 2009$ & $\begin{array}{l}\text { Provides for systematization of the nursing care and implementation of the nursing process in public or private } \\
\text { environments with a professional nursing care, and other provisions. }\end{array}$ \\
\hline $375 / 2011$ & Provides for the presence of the nurse in pre-hospital and inter-hospital care in situations of known or unknown risk. \\
\hline $376 / 2011$ & $\begin{array}{l}\text { Provides for the participation of the nursing staff in the process of transportation of patients in environment } \\
\text { internal to healthcare services. }\end{array}$ \\
\hline $422 / 2012$ & Normalizes the professional practice of the nurse in orthopedic care and orthopedic immobilization procedures. \\
\hline $424 / 2012$ & $\begin{array}{l}\text { Normalizes the duties of the nurse professionals in Material and Sterilization Center (CME - Centro de Material e } \\
\text { Esterilização) and in companies that process health products. }\end{array}$ \\
\hline $427 / 2012$ & Normalizes the nursing procedures for using mechanical restraint in patients. \\
\hline $450 / 2013$ & $\begin{array}{l}\text { Normalizes the procedure for vesical probe according to the Conselho Federal de Enfermagem /Conselho } \\
\text { Regional de Enfermagem system. }\end{array}$ \\
\hline $453 / 2014$ & Approves the technical standard that provides for the performance of the nursing staff in nutritional therapy. \\
\hline $464 / 2014$ & Normalizes the practice of the nursing staff in home care. \\
\hline $501 / 2015$ & Resolves to approve and establish the regulation on the competence of the nursing staff in the care of wounds. \\
\hline $511 / 2016$ & $\begin{array}{l}\text { Approves the technical standard that provides for the performance of nurses and nurse technicians in } \\
\text { hemotherapy. }\end{array}$ \\
\hline $567 / 2018$ & Regulates the practice of the nursing staff in the care of patients with wounds. \\
\hline
\end{tabular}




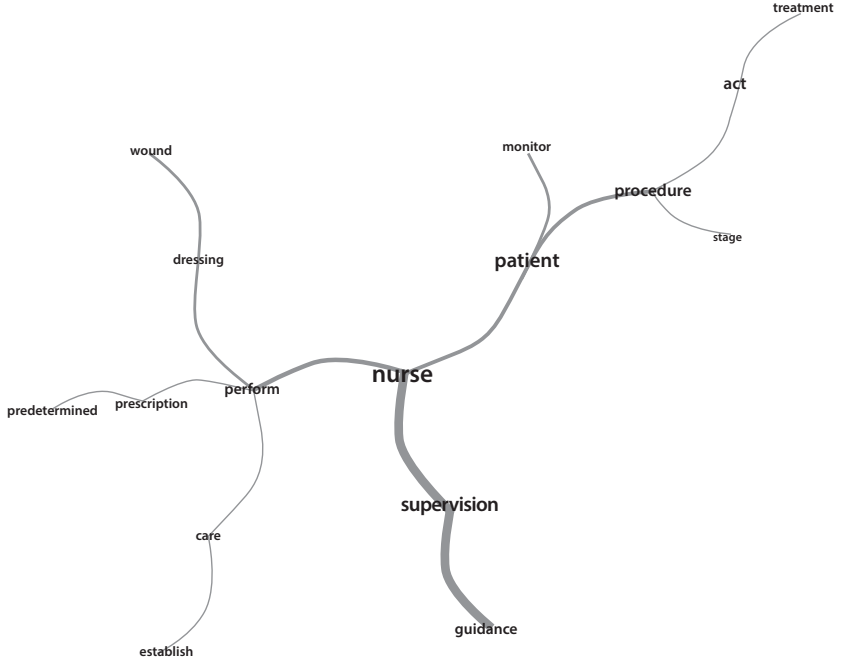

Figure 3 - Illustrative tree of the similarity analysis of resolutions of the Brazilian Federal Nursing Council

\section{DISCUSSION}

From the critical analysis of selected resolutions, categorization was held by content similarity and two categories were built for analysis: 1) nurse technician's areas of practice according to Cofen resolutions; and 2) description of activities performed by the nurse technician on the basis of Cofen resolutions.

\section{Nurse technician's areas of practice according to Cofen resolutions}

In practice, the nurse technician's area of practice is much more extensive than provided in the resolutions considered, since the latter bring potentially restricted and specific sectors. In other words, although there are indicative standards on the nurse technician's areas of practice, there still is not enough to standardize and regulate their practice, which can hinder the expansion of the field of these professionals in various sectors

Chart 2 - Characterization of the nurse technician's work process based on resolutions, 1975-2018

\begin{tabular}{|c|c|}
\hline $\begin{array}{l}\text { Conselho Federal } \\
\text { de Enfermagem } \\
\text { resolution No./year }\end{array}$ & Characterization of activities \\
\hline $210 / 1998$ & $\begin{array}{l}\text { To act on the prevention, treatment and minimization of side effects in clients undergoing chemotherapy anticancer } \\
\text { treatment. }\end{array}$ \\
\hline $211 / 1998$ & $\begin{array}{l}\text { To act with radiology examinations, as well as in the prevention, treatment and rehabilitation to clients subjected to ionizing } \\
\text { radiation. }\end{array}$ \\
\hline $214 / 1998$ & To act on surgical instrumentation. \\
\hline $358 / 2009$ & To participate in the implementation of the nursing process, under the supervision and guidance of the nurse. \\
\hline $375 / 2011$ & To act in any pre-hospital service, under direct supervision of the nurse. \\
\hline $376 / 2011$ & $\begin{array}{l}\text { To monitor the level of consciousness and vital functions, in accordance with the general state of the patient; to keep the } \\
\text { connection of endotracheal tubes, vesical probes and nasogastric tubes, chest tubes and intravenous catheters, ensuring the } \\
\text { hemodynamic and ventilatory support to the patient; to use protective measures to ensure the physical integrity of the patient. }\end{array}$ \\
\hline $422 / 2012$ & To act in the field of orthopedics and procedures related to orthopedic immobilization through training. \\
\hline $424 / 2012$ & To perform the activities prescribed in Standard Operating Procedures, under the guidance and supervision of a nurse. \\
\hline $427 / 2012$ & $\begin{array}{l}\text { To employ mechanical restraint of the patient under direct supervision of the nurse; to prevent adverse events and early } \\
\text { identify them; clinical monitoring of the level of consciousness, vital data and skin and circulation conditions in places and } \\
\text { members contained the patient, when the patient is under contention. }\end{array}$ \\
\hline $450 / 2013$ & $\begin{array}{l}\text { To perform activities prescribed by the nurse in the planning of assistance, such as monitoring and recording of the patient's } \\
\text { complaints, the conditions of the drainage system, the urine output; maintenance of clean technique when handling the } \\
\text { drainage system, urine collection for exams; monitoring of water balance - ingestion and elimination of liquids; under } \\
\text { supervision and guidance of the nurse. }\end{array}$ \\
\hline $453 / 2014$ & $\begin{array}{l}\text { To storage correctly the enteral feeding bottle for its conservation and integrity; to establish specific care with the route } \\
\text { of administration; care with the administration of nutrition, checking: medical record, bottle label, patient's name, route of } \\
\text { administration, volume and time; to monitor the patient during the procedure; to communicate to the multidisciplinary } \\
\text { team the intercurrences related to Nutritional Therapy. }\end{array}$ \\
\hline $464 / 2014$ & $\begin{array}{l}\text { To participate in the implementation of the home health nursing, to the extent suitable, under supervision and guidance of the } \\
\text { nurse. }\end{array}$ \\
\hline $501 / 2015$ & $\begin{array}{l}\text { To dress stage I and II wounds; to assist the nurse in dressing of stage III and IV wounds; to dress stage III wound, when delegated } \\
\text { by nurses; to guide the patient on the procedures held and wound care. }\end{array}$ \\
\hline $511 / 2015$ & $\begin{array}{l}\text { To promote general care to the patient according to the prescription of nursing or preestablished protocol; to perform procedures } \\
\text { that are prescribed or have preestablished protocol, using aseptic technique; to promote cautious identification of the blood } \\
\text { bag and tubes simultaneously; to conduct the prescription made by the nurse; to measure vital signs in the pre-, intra- and post- } \\
\text { transfusion procedure; to rigorously monitor the drip of blood or blood components. }\end{array}$ \\
\hline $567 / 2018$ & e wound under prescription and action of the nurse; to assist the nurse in the wounds. \\
\hline
\end{tabular}


and generate uncertainty as to what types of functions can be legally performed by these workers, which causes legal uncertainty regarding the performance of the tasks of the profession ${ }^{(12)}$.

This study highlights that the nurse technician's scope of performance as a member of the health team is regulated for the provision of nursing care to the individuals and population; and is ensured as legal prerogative to assist the nurse in the different levels of health care, in particular along with patients in critical state and/or with special demands and in the planning, programming, guidance and supervision of the activities of nursing care, as a member of the team.

\section{Description of the activities performed by the nurse tech- nician based on the Cofen resolutions}

Chart 2 shows that, besides acting in different care levels, nurse technicians can act in situations of patients with profiles of different complexities. Regarding the nursing care with practices normalized by Cofen, there are evidenced the attributions and procedures related to anticancer chemotherapy in services of hemotherapy, parenteral and enteral nutrition, and in wound care.

In this perspective, according to resolution No. 210/1998 ${ }^{(13)}$, the nurse technician can act in the scope of chemotherapy and care with anticancer drugs. However, drug administration is an attribution reserved to the nurse professional, being a responsibility of the nurse technician, in this context, to perform nursing actions under the direct supervision of the former ${ }^{(14)}$. Bearing that in mind, studies $^{(15-18)}$ recommend measures directed to the education of all those involved in this nursing area, evidencing the participation of nurse technicians and assistants, not only of nurse professionals.

Acting in the handling of chemotherapeutic and anticancer agents is a relevant practice of the nursing team in the oncology area, which requires a trained, qualified and skilled team to validate, prepare and apply these drugs ${ }^{(15,19)}$.

No studies related to the performance of nurse technicians in the scope of chemotherapy were found; concretely, this study observed a performance focused on the care with anticancer drugs and on the control of complications.

Resolution No. 211/1998 ${ }^{(20)}$ approaches the performance on the scope of ionizing radiation. Such specialty is responsible by the service to the patient in the pre-, intra- and post-procedure periods, involving $x$-ray technologies. The performance of these professionals is regulated by the aforementioned resolution, and the specialization is recognized by resolution No. 418/2011(21), for professionals of technical level. The nurse professional is within this framework based on his/her performance on conventional radiology, medical ultrasound, computed tomography and mammography, nuclear medicine, hemodynamics and magnetic resonance ${ }^{(22)}$.

It is known that ionizing radiation is harmful to health and can impair, especially biologically, the health of the exposed worker. However, nursing professionals are rarely included in personal monitoring programs and sometimes are not contemplated in specific training programs, besides having no recognized regulation as for the frequent exposure to these radiations ${ }^{(23)}$. In other words, despite the existence of specific laws that cover the radiation protection, there is a lack of norms aimed at nursing professionals.

Resolution No. 214/1998 ${ }^{(24)}$ covers the performance of the nurse technician in surgical instrumentation, but is limited to this. Its scope brings no guidance for this activity. The activities of circulation in the operating room and instrumentation are duly regulated and described in Decree No. 94.406/1987(5). However, to perform these functions, one must have specific training.

Still regarding the performance of the technician, resolution No. $358 / 2009^{(25)}$ covers the participation of this professional in the performance of the nursing process. For that, there is the Systematization of Nursing Care (SAE - Sistematização da Assistência de Enfermagem) as a organization and execution of the aforementioned process, with holistic view and composed by inter-related steps ${ }^{(6)}$. It is the essence of Nursing Practice, instrument and methodology of the profession and, as such, assists the nurse in making decisions, predicting and evaluating the consequences. However, despite the efforts of the professional category, the knowledge on SAE is still very fragile, culminating in limitations for its practical application $^{(26)}$. It is worth emphasizing that all nursing professionals are responsible for its performance; also,nurse technicians can act in the steps of Nursing Record and Care Implementation.

Among the several areas of performance of the nursing staff, there is the home care, which is regulated by the Cofen and covers a set of actions for health promotion, preventions and treatment of diseases and rehabilitations provided at home ${ }^{(27)}$. In this context, this study considers that the nurse technician performs mainly actions of measurement of vital signs, dressing of wounds, simple procedures and guidance on health care.

It is emphasized that home care, for providing new modes of care production and intervention at different spots of the network, offers the continuity and comprehensiveness of care; however, its practice is hindered mainly due to the lack of complementarity of care by other services of the healthcare network ${ }^{(28)}$.

As for hemotherapy attributions, this study considered the expansion of this area of practice and the challenge that such development proposes to Nursing, given that it demands specialized knowledge on the blood cycle process, from transfusion held in general hospital to blood donation in blood donor centers ${ }^{(29-30)}$.

Resolution No. 511/2016 ${ }^{(31)}$ states that nurses and nurse technicians may act at blood donor centers, provided that duly trained. The law prohibits nursing assistants from executing actions related to hemotherapy, except for care in hygiene and patient comfort, due to the high complexity of the therapy. The normative texts offer details on the competences of each professional category in the procedures of blood collection and blood transfusion, provided that nurse technicians participate in the care actions under supervision and guidance of the nurse.

Another important area of performance in nursing is wound care. Based on the regulation of this field of care, the access to proper material resources, to training and to interdisciplinary work were factors considered essential for an effective nursing care to patients with wounds ${ }^{(32)}$.

This study must consider that there are two resolutions $s^{(33-34)}$ that cover the performance of the nurse technician in the wound field. The first, issued in 2015, is different from the last, issued in 2018, because the latter states that the technician can dress the wound in any stage, whereas the former limits the performance to stage I and II wounds. This fact causes reflection and raises doubts as to why one of them was not revoked, given that both of them are valid and bring dubious orientation on the nurse technician's performance. 
Finally, it is emphasized that institutional fields of performance demand an extremely targeted and specific performance, as in ionizing radiation, surgical instrumentation, pre- and inter- hospital care, orthopedic care and procedures of orthopedic immobilization, mechanical contention of patients and transportation of patients in environment internal to health services ${ }^{(35)}$. Given this context, one must consider that, in relation to the resolutions issued by Cofen, there still is a path to be taken in relation to the nurse technician's performance in these spaces.

\section{Study limitations}

After analyzing the definitions for the nurse technician's performance in all the contexts covered in the resolution of the Brazilian Federal Council of Nursing, there is a clear frailty of theoretical and normative content to base the practice of the largest class acting in the scope of nursing and health. This fact impedes more consolidated results to be presented; besides, the lack of studies on the nurse technician's performance is clear, limiting the discussions around the theme.

\section{Contributions to the nursing field}

The social contribution of this study is based on the fact that this paper aims at analyzing the class of largest contingency of health work body, the nurse technicians, who substantially impact health and society. This is because such professionals, if well trained in their work process, tend to present a potential for improvement of the work process of this category, resulting in improvement of the health service provided to the population.

As for the scientific relevance, one must consider that the regulation of nursing - professional training, competences and performance areas included -, is issued by Cofen, and that there is a normative dispersion about the policy that bases the competences of the nurse technician professional. With that, this study contributes in the attempt of attending the need of deepening the performance of the nurse technician in Brazil, aiming to contribute to the literature about this theme.

\section{FINAL CONSIDERATIONS}

The results of this study allowed to understand how nurse technicians in Brazil have their performance ruled by their Professional Council, evidencing the normative bases for their practice and duly specifying the care in the profession. Given the above, one can observe that the nurse technician acts, according to the resolutions, in the scope of hemotherapy, chemotherapy, orthopedy, radiology, pre-hospital care, wound care, surgical center, as well as home and nutritional services.

A critical perspective is required given the results found, in which, from 364 existing resolutions, only 15 briefly cover the nurse technician's performance, who composes the largest work force in health. One still has to consider that the resolutions do not answer in their integrity to the questions of the study because the normative content is absolutely objective and without depth, which substantiates certain frailty and consequent need of normative complementation.

At last, the normative bases require expansion to the other nursing fields, since that resolutions refer to the practice of care in specific areas. This need becomes clear due to the outmoded contents, that are far from the current reality. Bearing that in mind, there is the law of the professional practice, Law $n^{\circ} 7.498$, formulated in 1986, and which, even today, is the normative foundation that guides the practice of nursing professionals.

Thus, this study suggests that debates, meetings and discussions should happen in order to consolidate the care policy of the profession and that, beyond that, a normative update of documents that make up the foundation occurs for the practice of Brazilian nursing.

\section{REFERENCES}

1. Peduzzi M, Anselmi ML. O processo de trabalho de enfermagem: a cisão entre o planejamento e execução do cuidado. Rev Bras Enfermagem [Internet]. 2002 [cited 2017 Aug 10];55(4):392-8. Available from: http://dx.doi.org/10.5935/0034-7167.20020086

2. Brasil. Lei n 7.498, de 25 de junho de 1986. Dispõe sobre a regulamentação do exercício da Enfermagem e dá outras providências. Diário Oficial da União [Internet]. 1986 June 26 [cited 2017 Oct 24]. Available from: http://www.planalto.gov.br/ccivil_03/LEIS/L7498.htm

3. Ministério da Educação (BR). Resolução n 7, de 18 de abril de 1977. Padrões mínimos-Curso de Técnicos e Auxiliares de Enfermagem. Diário Oficial da União. 1977 May 24.

4. Brasil. Lei n 13.415, de 16 de fevereiro de 2017. Altera as Leis nos 9.394, de 20 de dezembro de 1996, que estabelece as diretrizes e bases da educação nacional. Diário Oficial da União. 2017 Feb 17.

5. Andrade SR, Piccoli T, Ruoff AB, Ribeiro JC, Sousa FM. Normative grounds of health care practice in Brazilian nursing. Rev Bras Enferm [Internet]. 2016 [cited 2017 Aug 12];69(6):1020-8. Available from: http://dx.doi.org/10.1590/0034-7167-2016-0228

6. Conselho Federal de Enfermagem. Decreto n 94.406, 8 de julho de1987. Regulamenta a Lei n. 7.498, de 25 de junho de 1986, que dispõe sobre o exercício da enfermagem e dá outras providências. Diário Oficial da União [Internet]. 1987 June 9 [cited 2017 Oct 30 ]. Available from: http://www.cofen.gov.br/decreto-n-9440687_4173.html

7. Brasil. Lei n 5.905, de 12 de julho de 1973. Dispõe sobre a criação dos Conselhos Federal e Regionais de Enfermagem e dá outras providências. Diário Oficial da União [Internet]. 1973 July 13 [cited 2017 Oct 30]. Available from: http://www.cofen.gov.br/lei-n-590573-de-12-de-julho-de-1973_4162.html

8. Conselho Federal de Enfermagem [Internet]. Resoluções. c2019 - [cited 2019 Apr 25]. Available from: http://www.cofen.gov.br/categoria/ legislacao/resolucoes

9. Cellard A. Análise documental. In: Poupart JRM, Deslauriers J-P, Groulx L-H, Laperrière A, Mayer R, Pires AP. A pesquisa qualitativa: enfoques epistemológicos e metodológicos. Rio de janeiro: Vozes; 2012. p. 295-316. 
10. Ratinaud P. Iramuteq: Interface de R pour les Analyses Multidimensionnelles de Textes et de Questionnaires. [Internet] 2009 [cited 2018 Apr 04]. Available from: http://www. iramuteq.org/

11. Camargo BV, Justo AM. Tutorial para uso do software de análise textual Iramuteq. Florianópolis: Universidade Federal de Santa Catarina; 2013.

12. Bertonha JF. The corporatist thought in Miguel Reale: readings of Italian fascism in Brazilian integralismo. Rev Bras Hist [Internet]. 2013 [cited 2018 Oct 01];33(66):269-86. Available from: https://dx.doi.org/10.1590/S0102-01882013000200013

13. Conselho Federal de Enfermagem. Resolução n²10, de 1 de julho de 1998. Dispõe sobre a atuação dos profissionais de enfermagem que trabalham com quimioterápicos antineoplásicos. Rio de Janeiro; 1998.

14. Conselho Federal de Enfermagem. Resolução n 569, de 19 de fevereiro de 2018. Aprova o regulamento técnico da atuação dos profissionais de enfermagem em quimioterapia antineoplásica. Brasília, DF; 2018.

15. Ribeiro TS, Santos VO. Patient safety in administering antineoplastic chemoteraphy: an integrative review. Rev Bras Cancerol [Internet]. 2015 [cited 2017 Oct 12];61(2):145-53. Available from: http://pesquisa.bvsalud.org/portal/resource/pt/biblio-833822?lang=fr

16. Cirilo JD, Silva MM, Fuly PSC, Santos CF, Chagas Moreira M. A gerência do cuidado de enfermagem à mulher com câncer de mama em quimioterapia paliativa. Texto Contexto Enferm [Internet]. 2016 [cited 2017 Aug 22];25(3):1-9. Available from: http://www.redalyc.org/articulo.oa?id=71446759027

17. Souza NR, Bushatsky M, Figueiredo EG, Melo JTS, Freire DA, Santos ICRV. Oncological emergency: the work of nurses in the extravasation of antineoplastic chemotherapeutic drugs. Esc Anna Nery [Internet]. 2017 [cited 2017 Oct 20];21(1):e20170009. Available from: http://dx.doi. org/10.5935/1414-8145.20170009

18. Bruno MLM, Barbosa IM, Sales DS, Menezes AVB, Gomes AF, Alves MDS. Nursing procedures before extravasation of antineoplastic chemotherapeutic: standard operating protocol. Rev Enferm UFPE. 2014;8(4):974-80. doi: 10.5205/reuol.5829-50065-1-ED-1.0804201424

19. Kreidieh FY, Moukadem HA, El Saghir NS. Overview, prevention and management of chemotherapy extravasation. World J Clin Oncol [Internet]. 2016 [cited 2017 Oct 05];7(1):87-97. Available from: http://www.ncbi.nlm.nih.gov/pmc/articles/pmc4734939/

20. Conselho Federal de Enfermagem. Resolução n 211, de 1 de junho de 1998. Dispõe sobre a atuação dos profissionais de Enfermagem que trabalham com radiação ionizante. Brasília, DF; 1998.

21. Conselho Federal de Enfermagem. Resolução n 418, de 6 de dezembro de 2011. Atualiza, no âmbito do Sistema COFEN/Conselhos Regionais de Enfermagem, os procedimentos para registro de especialização técnica de nível médio em enfermagem. Brasília, DF; 2011.

22. Ministério da Saúde (BR). O SUS de A a Z: garantindo saúde nos municípios. Brasília, DF: Ministério da Saúde; 2005.

23. Huhn A, Melo JAC, Vargas MAO, Schneider DG, Lança L, Trentin D. Proteção radiológica: da legislação à prática de um serviço. Enferm Foco. 2016;7(2):27-31.

24. Conselho Federal de Enfermagem. Resolução n 214, de 10 de novembro de 1998. Dispõe sobre a instrumentação cirúrgica. Rio de Janeiro; 1998.

25. Conselho Federal de Enfermagem. Resolução n 358, de 15 de outubro de 2009. Dispõe sobre a sistematização da assistência de enfermagem e a implementação do processo de enfermagem em ambientes, públicos ou privados, em que ocorre o cuidado profissional de enfermagem, e dá outras providências. Brasília, DF; 2009.

26. Salvador PTCO, Rodrigues CCFM, Bezerril MS, Ferreira LL, Chiavone FBT, Virgílio LA, et al. Percepções de profissionais de enfermagem acerca da integração do técnico de enfermagem na sistematização da assistência. Esc Anna Nery [Internet]. 2017 [cited 2018 Jan 14];21(2):e20170035. Available from: http://dx.doi.org/10.5935/1414-8145.20170035

27. Braga PP, Sena RR, Seixas CT, Castro EAB, Andrade AM, Silva YC. Oferta e demanda na atenção domiciliar em saúde. Ciênc Saúde Colet [Internet]. 2016 [cited 2018 Jan 05];21(3):903-12. Available from: http://www.scielo.br/pdf/csc/v21n3/1413-8123-csc-21-03-0903.pdf

28. Andrade AM, Silva KL, Seixas CT, Braga PP. Atuação do enfermeiro na atenção domiciliar: uma revisão integrativa da literatura. Rev Bras Enferm [Internet]. 2017 [cited 2018 Jan 14];70(1):210-19. Available from: http://dx.doi.org/10.1590/0034-7167-2016-0214

29. Mattia D, Andrade SR. Cuidados de enfermagem na transfusão de sangue: um instrumento para monitorização do paciente. Texto Contexto Enferm [Internet]. 2016 [cited 2018 Jan 14];25(2):e2600015. Available from: http://dx.doi.org/10.1590/0104-07072016002600015

30. Silva Jr JB, Rattner D. A Vigilância Sanitária no controle de riscos potenciais em serviços de hemoterapia no Brasil. Saúde Debate [Internet]. 2016 [cited 2018 Jan 14];40(109):136-53. Available from: http://dx.doi.org/10.1590/0103-1104201610911

31. Conselho Federal de Enfermagem. Resolução n॰ 511, de 31 de março de 2016. Aprova a norma técnica que dispõe sobre a atuação de enfermeiros e técnicos de enfermagem em hemoterapia. Brasília, DF; 2016.

32. Oliveira FP, Oliveira BGRB, Santana RF, Silva BP, Candido JSC. Classificações de intervenções e resultados de enfermagem em pacientes com feridas: mapeamento cruzado. Rev Gaúcha Enferm [Internet]. 2016 [cited 2018 Jan 14];37(2):e55033. Available from: http://www.scielo.br/ pdf/rgenf/v37n2/0102-6933-rgenf-1983-144720160255033.pdf

33. Conselho Federal de Enfermagem. Resolução n 501, de 9 de dezembro de 2015. Resolve aprovar e instituir o regulamento sobre a competência da equipe de enfermagem no cuidado às feridas. Brasília, DF; 2015.

34. Conselho Federal de Enfermagem. Resolução n 567, de 29 de janeiro de 2018. Regulamenta a atuação da equipe de enfermagem no cuidado aos pacientes com feridas. Brasília, DF; 2018.

35. Nascimento ACEC, Pinto ALR, Pereira CRA, Souza FEP, Vieira ZRS, Andrade GDB, et al. A importância da supervisão de enfermagem nas instituições de saúde. Rev Saúde Pesqui. 2013 [cited 2018 Jan 14];6(2):339-43. Available from: http://dx.doi.org/10.17765/1983-1870.2013v6n2p\%25p 